\title{
Incidence of cancer among welders of mild steel and other shipyard workers
}

\author{
Tor Erik Danielsen, Sverre Langård, Aage Andersen, Øistein Knudsen
}

\begin{abstract}
The incidence of cancer among 4571 shipyard workers with first employment between 1940 and 1979, including 623 welders of mild steel, was investigated in a historical cohort study. The loss to follow up was $1 \cdot 1 \%$. The total number of deaths was 1078 (974.5 expected) and there were 408 cases of cancer $v 361 \cdot 3$ expected. Sixty five cases of lung cancer were found $v 46.3$ expected based on the national rates for males. Four pleural mesotheliomas had occurred (1.2 expected), none among the welders. An excess of lung cancers was found among the welders (nine cases $v \mathbf{3 . 6}$ expected). There were six cases of lung cancer $v \quad 1.6$ expected in a high exposure group of 255 welders. A survey of the smoking habits as of 1984 indicated $10 \%-20 \%$ more daily smokers among the shipyard production workers than among Norwegian males. Exposure to smoking and asbestos were confounding variables in this study.
\end{abstract}

(British fournal of Industrial Medicine 1993;50:1097-1103)

The possible relation between exposure to welding fumes and development of cancer has been investigated in several studies, ${ }^{1-11}$ many of which have indicated the presence of an increased incidence or mortality from lung cancer among welders. ${ }^{1-8}$ Smoking, asbestos, and work related exposure other than to welding fumes are potential confounding factors in these studies. ${ }^{12}$ It has been suggested, however that an increased incidence of lung

Telemark Central Hospital, Department of Occupational Medicine, N-3906 Porsgrunn, Norway T E Danielsen, S Langård

Cancer Registry of Norway, Montebello, N-0310 Oslo, Norway

A Andersen

Health Department, Haugesund

Verksted, N-5500 Haugesund, Norway

Mekaniske

$\emptyset$ Knudsen cancer of $30 \%-40 \%$ among welders results from specific exposures related to welding. ${ }^{113}$

Changes in welding methods and steel alloys often result in a complex exposure among welders. An excess risk of cancer in subgroups of welders who mainly welded on stainless steel and thus are exposed to hexavalent chromium has been suggested. ${ }^{14}$

The aim of our study was to investigate the incidence of cancer among shipyard welders, mainly welding manual metal arc welding on mild steel, in a long term follow up. The study is the second in a series of epidemiological investigations among Norwegian shipyard workers. ${ }^{2}$ It was aimed at studying whether the welders had an increased risk of lung cancer.

\section{Material and methods}

THE SHIPYARD

The shipyard is located on the west coast of Norway and was established in 1900 as a service yard. After the second world war the shipyard expanded into ship repair and ship conversions. The first ship was built in 1943. Large scale shipbuilding began in the 1950 s. Gradually the yard specialised in all welded special purpose ships. Repair of merchant ships has remained a smaller part of the yard's production throughout the years. By 1977 the yard started construction for the offshore oil industry. Constructions for the North Sea oil industry have been the primary products from 1984 onwards.

\section{WELDING}

Only seven gas welders were employed at the yard before 1940. Electric welding was introduced about 1940 and manual metal arc welding became the predominant method. Uncoated and acidic coated electrodes were used up to the early 1950s. These electrodes produced an abundance of fumes and were considered to have poor metallurgic properties. By the mid 1950s basic coated electrodes were mainly used. In the 1970 s gas shielded welding and tungsten inert gas welding were introduced at the yard.

Welding on aluminium and on zinc primed steel 
occasionally took place before 1970. Until 1976 welding was performed mainly on mild steel. From 1977 onwards stainless steel was gradually introduced and by 1990 about $50 \%$ of the welding arc time was carried out on stainless steel.

\section{ENVIRONMENTAL MONITORING}

In 1973 and 1985 a series of environmental air samples were taken at the yard. In 1973 asbestos particles were found, but concentrates in the air could not be determined exactly. The welding fume samples showed concentrations of total dust from 0.8 to $9.5 \mathrm{mg} / \mathrm{m}^{3}$ (median $2.5 \mathrm{mg} / \mathrm{m}^{3}$ ). Traces of chromium were found in the samples. Analyses for nickel were not carried out.

In 1985 sampling was carried out both in the machine shop and the welding shop. Concentrations of total dust ranged from 0.6 to 22 $\mathrm{mg} / \mathrm{m}^{3}$ (median $2.6 \mathrm{mg} / \mathrm{m}^{3}$ ). All chromium concentrations were below $0.05 \mathrm{mg} / \mathrm{m}^{3}$. For Ni the results in the welding shop ranged from the lowest detectable concentration of $0.01 \mathrm{mg} / \mathrm{m}^{3}$ to $0.04 \mathrm{mg} / \mathrm{m}^{3}$.

\section{HISTORICAL EXPOSURE ASSESSMENT}

There is some documentation on previous work exposure from written reports and interviews with veterans. Up to the early 1950 s the work environment for welders was reported to be poor. Gloves, eye protection, and welding shields were used, but the welders hardly ever used respirators. Fans were available for blowing air into the work area when welding was in confined spaces. Exhaust ventilation came into regular use from the late 1960s onwards. The workers' environment gradually improved from the 1950 s to the 1970 s.

\section{USE OF ASBESTOS}

Asbestos was used at the shipyard until the early 1970s for insulation of pipes and machinery and as heat insulation in the ships. According to the administrators the asbestos was exclusively chrysotile. Some welders used asbestos for heat protection. Asbestos was also removed from ships during repair. From the early 1960s onwards most of the handling of asbestos was taken over by external firms. Groups of shipyard workers involved in production-for example, boilermakers, pipefitters, and carpenters, could have been exposed, however.

\section{SMOKING HABITS}

Limited information on smoking habits are available. The occupational health services at the shipyard have recorded the smoking habits among the employees since 1983. Based on these data a survey on the current and former smoking habits as of 1984 was carried out. Table 1 shows the smoking habits of 997 workers employed by 1 January 1984 .
Table 1 Demographic data for 997 male shipyard workers in 1984

\begin{tabular}{lcccc}
\hline & $\begin{array}{l}\text { All } \\
\text { employees } \\
\text { No (\%) }\end{array}$ & $\begin{array}{l}\text { Whipyard } \\
\text { No (\%) }\end{array}$ & $\begin{array}{l}\text { Shoduction } \\
\text { workers } \\
\text { No }(\%)\end{array}$ & $\begin{array}{l}\text { Male } \\
\text { national } \\
(\%) t\end{array}$ \\
\hline \multicolumn{5}{c}{ Smoking habits } \\
Daily smokers & $510(53)$ & $93(55)$ & $332(54)$ & 42 \\
Former smokers & $256(27)$ & $45(26)$ & $156(26)$ & 58 Non- \\
Never smokers & $187(20)$ & $32(19)$ & $121(20)$ & smokers \\
Non-responders & 44 & 10 & 18 & \\
\multicolumn{7}{c}{} \\
$16-24$ & Age distribution; prevalence of daily smokers \\
$25-34$ & $135(61)$ & $25(56)$ & $101(62)$ & 32 \\
$35-44$ & $188(62)$ & $37(73)$ & $113(61)$ & 44 \\
$45-54$ & $231(58)$ & $41(51)$ & $145(61)$ & 48 \\
$55-74$ & $181(52)$ & $34(44)$ & $119(55)$ & 42 \\
\hline
\end{tabular}

*Work categories $3,4,5,9,10,11,12,14$ (never 1): see table 3 . †From the Norwegian National Council on Tobacco and Health.

The prevalence of daily smokers was $10 \%-20 \%$ higher both among the welders and a subcohort of shipyard production workers than among the Norwegian male population at the time. ${ }^{15}$

A high proportion of the young workers were smokers, with a significant decline in the prevalence of daily smokers with age. The same tendency, but not as strong, is present in the rates for Norwegian men.

\section{SUBJECTS AND METHODS}

The personnel register was used as the source for the names of the employees. This register was established together with the yard. Information on individual employment was complete up to 1 August 1990. All employees with first employment after 1 January 1940 were registered with name, date of birth, and dates for starting and ending work for up to five employment periods.

The study was restricted to male workers first employed between 1 January 1940 and 31 December 1979. Metal arc welding started about 1 January 1940 so this date was chosen as the starting date. Workers employed after 31 December 1979 were excluded to allow at least 10 years of development time for cancer. A total of 4711 workers were compiled for the study. Ten were excluded due to lack of name or date of birth. Sixteen foreigners and $53(1.1 \%)$ men who could not be traced were excluded from the remaining 4701 . Sixty one men had emigrated or died before the follow up. Sixty eight men who had emigrated later remained under study until their year of emigration. The ultimate cohort comprised 4571 subjects.

Job titles changed during the study period. In cooperation with employees from the personnel office and former production workers the numbers of work categories were limited to 15 that were 
considered to be relevant. The categories were established to reflect the work organisation of the yard. Categories were established for the production workers and those engaged in support functions as well as for office personnel. All participants were stratified into these categories according to their work.

There were 623 welders in the cohort of whom many could have previously been employed as welders in other enterprises. The stratification on duration of employment in selected work categories was based on the worker's total duration of employment. Thus the duration of employment in the present workplace was not regarded as the best way of identifying surrogates for exposure.

A separate group of 263 welders were classified as a high exposure group based on certain criterianamely, more than three years of employment as welder at the yard and being identified as certified welder by veterans. Among these, a subgroup of 223 welders was followed up from the year that each one had been employed as a welder for five years at the yard. This subgroup was considered as having a very high exposure.

An internal reference group was established comprising all shipyard production workers other then welders and burners. Work categories $3,4,5$, $9,10,11,12$, and 14 (see table 3) were used. After having excluded 72 ever welders (never 1), this group of shipyard production workers comprised 3325 workers. To avoid misclassification among the different categories of production workers, retired workers were interviewed about details of their own as well as their colleagues' work histories. The workers were assigned to their final work categories before their health state was examined.

The Cancer Registry of Norway has registered all new cases of cancer occurring in the Norwegian population since 1 January 1953 . The registration of all new cases is more than $99 \%$ complete for solid tumours. Registration is based on compulsory reporting from hospitals and pathologists.

\section{STATISTICAL METHODS}

Many workers held more than one job during their employment at the yard. All calculations were made considering each work period separately. Thus one worker with a known cancer could contribute to more than one work category, but only once when the incidence of cancer for the total cohort was considered.

Three subcohorts of workers were all compared directly with shipyard production workers (work categories $3,4,5,9,10,11,12$, and 14 only) with the EGRET program package for Poisson regression analysis of relative risks. The subcohorts were welders (work category 1 only), burners (work category 2 only), and office personnel and those engaged in support functions combined (work categories $6,7,8$, and 13 only). No external incidence rates were used.

Our observations started in 1953 and continued to 1990 or to the middle of the year of death or emigration. The individual worker was under observation from the middle of the year of first employment in the specified work category or if first employed earlier from the beginning of 1953 . The results are based on a comparison of observed (O) and expected (E) number of cancers. The expected numbers are based on five year age specific incidence rates for Norwegian males for each calendar year from 1953 to 1990.

The $95 \%$ confidence intervals $(95 \% \mathrm{CIs})$ were estimated on the assumption of a Poisson distribution of events with the use of a two sided test of significance. Standardised incidence rates (SIRs) were taken as rates between the observed and expected numbers of cases.

\section{Results}

There were 4571 workers participating in the cohort contributing 109580 person years to the study. In the whole cohort 1078 deaths of all causes occurred $v 974.5$ expected. An excess incidence of cancer of all sites was also found $(\mathrm{O} / \mathrm{E}=$ $408 / 361 \cdot 3)$. Sixty five cases of lung cancer were found $v 46.3$ expected (table 2). An increased incidence of unspecified cancer, and cancer of the colon, occurred. There were 22 cases of bladder cancer $v 24.0$ expected, and four cases of pleural mesothelioma $v 1.2$ expected. These four cases were recruited from three work categories; two worked as machine shop workers, one as a carpenter, and one as an electrician.

Lung cancer was in excess in several work categories (table 3 ). The excess was statistically signifi-

Table 2 Observed (O) and expected (E) cases of cancer at selected sites in 4571 shipyard workers

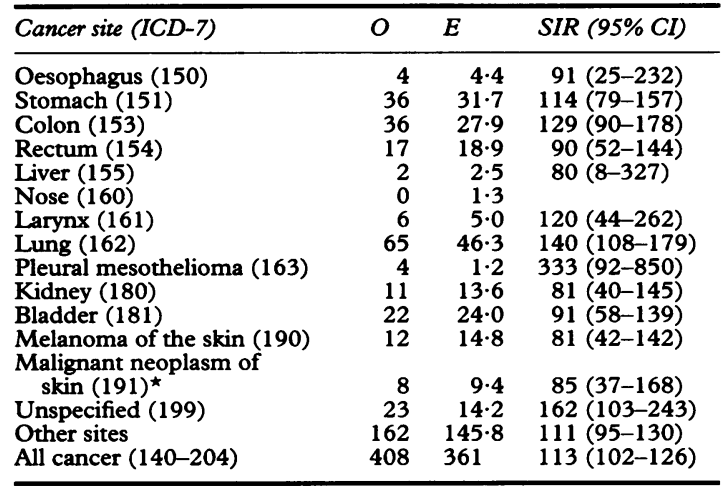

^Basal cell carcinoma excluded.

ICD-7 = International Classification of Diseases-seventh revision. 
Table 3 Observed (O) and expected (E) cases of lung cancer (code 162 of ICD-7) among the shipyard workers according to their work category*

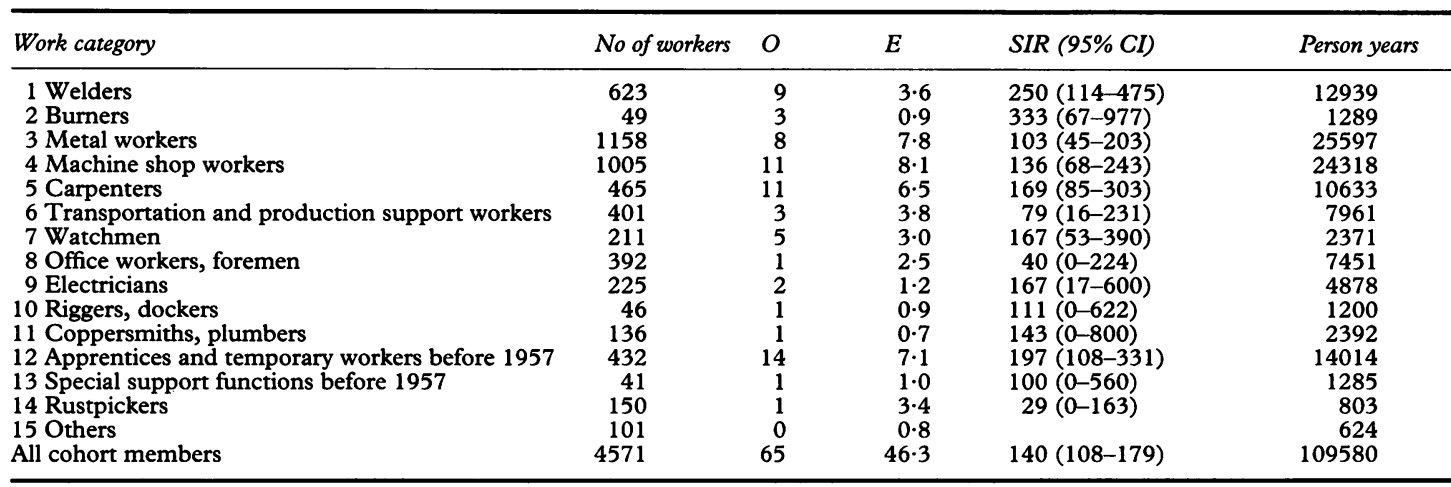

^Ever holding a job in the category.

cant among the welders $(\mathrm{O} / \mathrm{E}=9 / 3.6,95 \% \mathrm{CI}$ 114-475), and among the apprentices and the group of temporary workers $(\mathrm{O} / \mathrm{E}=14 / 7 \cdot 1,95 \%$ CI 108-331). The apprentices and the temporary workers comprised almost entirely apprentices leaving before graduation or temporary workers hired for short periods. They were employed before the end of 1957. The apprentices hired after 1957 were assigned directly to their particular work category.

Table 4 shows the distribution of total cancer and lung cancer with decade of first employment for the total cohort and for the welders. The excess cancer among the shipyard workers was most pronounced for those with first employment between 1950 and $1969(\mathrm{O} / \mathrm{E}=175 / 141)$. The excess lung cancer was most pronounced for shipyard workers employed between 1960 and $1969(\mathrm{O} / \mathrm{E}=17 / 9 \cdot 2)$. The welders presented an increased number of total cancer cases in all employment periods except between 1970 and 1979. The excess lung cancer was most pronounced among those hired between 1940 and the end of $1959(\mathrm{O} / \mathrm{E}=5 / 1 \cdot 4)$. One case of lung cancer was found in a worker employed at the yard before 1980, but with his first employment as a welder in the 1980 s.

For table 5, a development time of 15 years was accounted for by excluding observed and expected numbers for the first 15 years since first employ- ment. The first employment was either first employment at the yard for the total cohort or first employment in a specific job at the yard for a work category. There were 56 cases of lung cancer in the total cohort $v 37.3$ expected. Eight cases of lung cancer developed $v 2.6$ expected among the 587 welders under study more than 15 years after first employment as a welder. There were six cases of lung cancer $v 1.6$ expected in the high exposureco group of 255 welders. Four cases of lung cancer $v$ ? 1.0 expected were found among the separate subgroup of 207 very highly exposed welders. These cases of lung cancer developed more than 15 years after reaching the five year threshold of employment. All these results are different from unity. There were three cases of lung cancer among the 45 burners $v 0.8$ expected. In the internal reference group of 3110 shipyard production workers there were 38 cases of lung cancer $v 28 \cdot 1$ expected.

Table 6 shows a comparison of the incidence of cancer at selected sites among welders and shipyard production workers. As well as the findings for lung cancer the welders had an increased risk of melanoma of the skin, other skin cancers, cancer of the stomach, and rectal cancer. The shipyard production workers had a significantly raised incidence of pleural mesothelioma and cancer of the colon $(\mathrm{O} / \mathrm{E}=31 / 19 \cdot 8)$. The observed numbers of cancer

Table 4 Incidence of all cancers and lung cancer according to decade of first employment at the yard or as welder

\begin{tabular}{|c|c|c|c|c|c|c|}
\hline \multirow[b]{2}{*}{ Period } & \multicolumn{3}{|l|}{ Total cohort } & \multicolumn{3}{|l|}{ Welders } \\
\hline & Total (No) & Cancer $O / E$ & Lung cancer $O / E$ & Total (No) & Cancer $O / E$ & Lung cancer $O / E$ \\
\hline $\begin{array}{l}40-49 \\
50-59 \\
60-69 \\
70-79 \\
80-89\end{array}$ & $\begin{array}{r}1074 \\
735 \\
1197 \\
1565\end{array}$ & $\begin{array}{c}183 / 174 \\
89 / 69 \cdot 9 \\
86 / 71 \cdot 1 \\
50 / 46 \cdot 2\end{array}$ & $\begin{array}{c}30 / 22 \cdot 1 \\
12 / 9 \cdot 3 \\
17 / 9 \cdot 2 \\
6 / 5 \cdot 7\end{array}$ & $\begin{array}{c}29 \\
60 \\
166 \\
357 \\
11^{\star}\end{array}$ & $\begin{array}{r}7 / 4 \cdot 1 \\
9 / 5 \cdot 4 \\
14 / 8 \cdot 2 \\
7 / 7 \cdot 9 \\
1 / 0 \cdot 1\end{array}$ & $\begin{array}{l}2 / 0 \cdot 6 \\
3 / 0 \cdot 8 \\
1 / 1 \cdot 3 \\
2 / 0 \cdot 9 \\
1 / 0 \cdot 02\end{array}$ \\
\hline
\end{tabular}

^First employment at the yard before 1980 and first employment as welder after 1980. 
Table 5 Observed (O) and expected (E) cases of lung cancer (code 162 of ICD-7) for selected work categories according to employment in the selected category only (development time of 15 years has been accounted for)

\begin{tabular}{|c|c|c|c|c|c|}
\hline Work category & No of workers & $O$ & $E$ & $\operatorname{SIR}(95 \% C I)$ & Person years \\
\hline Welders & 587 & 8 & $2 \cdot 6$ & $308(135-608)$ & 4478 \\
\hline High exposure group of welders & 255 & 6 & 1.6 & $375(138-819)$ & 2413 \\
\hline Very high exposure group of welderst & 207 & 4 & $1 \cdot 0$ & $400(110-1020)$ & 1016 \\
\hline Burners & 45 & 3 & 0.8 & $375(75-1100)$ & 783 \\
\hline Shipyard production workers except welders and burners $\ddagger$ & 3110 & 38 & $28 \cdot 1$ & $135(96-186)$ & 31329 \\
\hline Total cohort & 4254 & 56 & $37 \cdot 3$ & $150(113-195)$ & 53824 \\
\hline
\end{tabular}

*Welders with more than three years employment at the yard as welders.

tSubgroup of welders followed up from the year each one had been employed for five years. The cases developed more than 15 years after reaching this threshold of exposure.

$\ddagger$ Work categories $3,4,5,9,10,11,12,14$ (never 1 ).

of the rectum was eight $v 13.5$ expected for shipyard workers.

Table 7 shows the incidence of lung cancer in selected work subcategories by total duration of all employment periods for each worker. Six cases of lung cancer occurred among the welders with $\geqslant 10$ years of employment $v 1.6$ expected. An excess of cancers was found $(\mathrm{O} / \mathrm{E}=37 / 22 \cdot 5)$ among shipyard production workers (never welders) employed for less than five years. The work category for apprentices and temporary workers before 1958 included 14 cases of lung cancer $v 7 \cdot 1$ expected. All the cases developed among those employed for less than five years $(\mathrm{O} / \mathrm{E}=14 / 6 \cdot 5)$.

Table 8 compares three subcohorts with groups of shipyard production workers directly by relative risks. Welders with more than five years of employment as a welder had an increased rate ratio of 3.0 $(95 \%$ CI $1 \cdot 3-6 \cdot 9)$. With a lag time of 10 years after entering this subgroup the rate ratio increased to $3 \cdot 2(95 \%$ CI $1 \cdot 3-8 \cdot 1)$. The welders with employment of less than five years had a rate ratio of 1.6 without and 1.7 with a lag time. The rate ratios for the burners were between $2 \cdot 3$ and $2 \cdot 6$. The subcohort consisting of office personnel and production support workers had rate ratios between 0.7 and $0 \cdot 8$.

\section{Discussion}

The personnel register was the source of individual information. Selection in recruitment cannot be expected when comparing welders and other shipyard production workers. Case ascertainments are comparable across the determinant contrasts.

There was an increased incidence of lung cancer in the total cohort (SIR 140). Increased incidences of unspecified cancers (SIR 162) and of all cancers (SIR 113) were also found. Two small subgroups, the burners (SIR 333) and the apprentices and temporary workers before 1957 (SIR 197), had higher incidences of lung cancer than had the total cohort. The findings among the 49 burners could be related to their work exposure. ${ }^{16}$ All the apprentices with lung cancer had been employed for less then five years at the yard. That subcohort consists to a large extent of unskilled workers. Thus the increased rate of lung cancer could be related to personal exposure factors and work related exposure at other workplaces. This unhealthy effect among short term workers has also been found in a similar study at another shipyard. ${ }^{2}$

A main finding of this study is the increased incidence of lung cancer (SIR 250) among shipyard welders. The SIR increased when 15 years of development time since first employment as a welder

Table 6 Observed $(O)$ and expected (E) cases of cancer at selected sites among 623 shipyard welders and 3325 shipyard production workers

\begin{tabular}{|c|c|c|c|c|c|c|}
\hline \multirow[b]{2}{*}{ Cancer site (ICD-7) } & \multicolumn{3}{|c|}{ Welders } & \multicolumn{3}{|c|}{ Shipyard production workers * } \\
\hline & $O$ & $E$ & $\operatorname{SIR}(95 \% C I)$ & $O$ & $E$ & $\operatorname{SIR}(95 \% C I)$ \\
\hline
\end{tabular}

*Work categories $3,4,5,9,10,11,12,14$ (never 1 ).

†Basal cell carcinomas excluded. 
Table 7 Observed (O) and expected (E) cases of lung cancer (code 162 of ICD-7) for workers in selected work categories according to total duration of employment at the yard (person-years (PY) at risk are attributed to each group)

\begin{tabular}{|c|c|c|c|c|c|c|c|c|c|c|c|c|}
\hline \multirow[b]{3}{*}{ Work category } & \multicolumn{12}{|c|}{ Duration of employment } \\
\hline & \multicolumn{3}{|c|}{$\leqslant 6$ months } & \multicolumn{3}{|c|}{6 months -4 years } & \multicolumn{3}{|c|}{$5-9$ years } & \multicolumn{3}{|c|}{$\geqslant 10$ years } \\
\hline & $O$ & $E$ & $P Y$ & $O$ & $E$ & $P Y$ & $O$ & $E$ & $P Y$ & $O$ & $E$ & $P Y$ \\
\hline Welders & 1 & 0.5 & 2544 & 2 & 0.9 & 5372 & 0 & 0.5 & 2203 & 6 & $1 \cdot 6^{\star}$ & 2821 \\
\hline $\begin{array}{l}\text { Shipyard production } \\
\text { workerst }\end{array}$ & 18 & $11 \cdot 0$ & 23967 & 19 & $11 \cdot 5$ & 33918 & 4 & $3 \cdot 6$ & 10778 & 4 & $7 \cdot 5$ & 13018 \\
\hline $\begin{array}{l}\text { Apprentices and } \\
\text { temporary workers } \\
\text { before } 1958 \ddagger\end{array}$ & 5 & $2 \cdot 5$ & 5131 & 9 & $4 \cdot 0$ & 7752 & 0 & $0 \cdot 4$ & 808 & 0 & $0 \cdot 2$ & 323 \\
\hline All cohort members & 21 & $13 \cdot 5$ & 30377 & 24 & $15 \cdot 3$ & 44822 & 8 & $5 \cdot 2$ & 15140 & 12 & $12 \cdot 3$ & 19241 \\
\hline
\end{tabular}

*95\% CI 138-819.

tWork categories $3,4,5,9,10,11,12,14$ (never 1$)$.

¥Work category 12 only.

was accounted for. A rate ratio of 3.0 was found when welders and shipyard workers with more than five years of employment were compared directly in a multiplicative risk model.

The highest risk of lung cancer among welders occurred in the subcohort with more than 10 years of employment at the yard (table 7) and in a high exposure group of welders (table 5). This high exposure group approached a fourfold excess risk of lung cancer (SIR 375), which is higher than reported in previous cohort studies. ${ }^{124578}$ These subcohorts seem to represent welders with a high risk of lung cancer. Their exposure in the 1940s and 1950 s is likely to have been high, and allows a long time for development. ${ }^{17}$ A retrospective cohort study among Finnish welders did not show the same effect on exposure in this period. ${ }^{9}$

These stratifications have limitations because the material only accounts for the employment periods at the yard. The yard is located in an area of maritime traditions, and a proportion of the shipyard workers had worked on board merchant ships before employment at the yard.

Use of lead and later zinc chromate primers could contribute to the increased risk of lung cancer among several categories of shipyard workers. ${ }^{18}$

Exposure to asbestos at the yard could to some extent explain the excess of lung cancer in the cohort. ${ }^{19} 20$ Shipyard production workers had probably been exposed to asbestos before 1970. There were four cases of pleural mesotheliomas but none among the welders. The veteran workers reported that some carpenters used asbestos for insulation, and that metal workers made asbestos cushions for boiler and pipe insulation. It was conceivable that these work categories comprise subgroups of workers with a significant exposure to asbestos. Thus the differences in the distribution of exposure to asbestos could probably not explain the increase in rates of lung cancer in welders compared with other shipyard production workers.

The 1984 survey on smoking habits indicated? that the production workers had a proportion of daily smokers $15-20 \%$ higher than Norwegian males. ${ }^{15}$ In $1964-5$ a survey was performed on the smoking habits in Norway, indicating $10 \%$ more smokers among blue collar workers than the average. ${ }^{21}$ The differences in smoking habits suggest, according to Axelson's formula, ${ }^{22}$ that lung cancer caused by smoking alone could amount to an SIR of about 125. The decreased SIR of bladder cancer, however, could indicate a possible overestimation of the effect of smoking in this study. The differences in smoking habits are unlikely to explain the discrepancies in the incidence ratios of lung cancer between the different categories of shipyard pro-

Table 8 Three subcohorts of welders, burners, office workers, and other workers engaged in production support functions compared with other shipyard production workers in an EGRET analysis of relative risks

\begin{tabular}{|c|c|c|c|c|}
\hline \multirow[b]{3}{*}{ Subcohorts } & \multicolumn{2}{|c|}{ Without lag time } & \multicolumn{2}{|c|}{ With lag time ( 10 years) } \\
\hline & $\begin{array}{l}\text { Employment } \\
\leqslant 5 y\end{array}$ & $\begin{array}{l}\text { Employment } \\
>5 y\end{array}$ & $\begin{array}{l}\text { Employment } \\
\leqslant 5 y\end{array}$ & $\begin{array}{l}\text { Employment } \\
>5 y\end{array}$ \\
\hline & $R R(95 \% C I)$ & $R R(95 \% C I)$ & $R R(95 \% C I)$ & $R R(95 \% C I)$ \\
\hline $\begin{array}{l}\text { Welders }{ }^{\star} \\
\text { Burners } \dagger \\
\text { Office workers and workers in production supportł }\end{array}$ & $\begin{array}{l}1.7(0.5-5 \cdot 5) \\
2 \cdot 4(0.6-9.9) \\
0.7(0.3-1.6)\end{array}$ & $\begin{array}{l}3 \cdot 0(1 \cdot 3-6 \cdot 9) \\
2 \cdot 3(0 \cdot 3-16 \cdot 4) \\
0 \cdot 7(0 \cdot 3-2 \cdot 0)\end{array}$ & $\begin{array}{l}1 \cdot 8(0 \cdot 5-5 \cdot 7) \\
2 \cdot 6(0 \cdot 6-10 \cdot 6) \\
0 \cdot 7(0 \cdot 3-1 \cdot 9)\end{array}$ & $\begin{array}{l}3 \cdot 2(1 \cdot 3-8 \cdot 1) \\
2 \cdot 6(0 \cdot 4-19 \cdot 1) \\
0 \cdot 8(0 \cdot 3-2 \cdot 6)\end{array}$ \\
\hline
\end{tabular}

$\star$ Only work category 1 ; fonly work category 2 ; fonly work categories $6,7,8$ and 13 ; fonly work categories $3,4,5,9,10,11,12,14$; $R R=$ rate ratio. 
duction workers. ${ }^{23} 24$ The increased risk of lung cancer (SIR 135) among shipyard production workers compared with Norwegian males was too low to be considered a confounding factor on the basis of differences in smoking habits and exposure to asbestos (table 5). ${ }^{22}$ The welders, however, had a threefold excess risk of lung cancer (SIR 308).

The ultra violet radiation from the welding process could have contributed to the excess risks of melanoma of the skin. ${ }^{16}$ Among the shipyard workers there were increased risks of cancer of the colon (SIR 157) and of pleural mesotheliomas (SIR 444). Both for welders and other subcohorts an excess was identified for cancers of the colon and rectum, which cannot be explained by work exposure.

A possible relation between exposure to welding fumes and development of lung cancer was scrutinised in the present study. Employment as a welder at the yard serves as the substitute for individual exposure data. It is likely that there was a decline in the amount of overall exposure from 1940 to 1970. The exposure from 1970 until the present is more complex due to the introduction of new technologies and stainless steel. Another problem is the lack of information on work related exposure outside the yard.

The findings in this study indicate that there is a group of highly exposed welders of mild steel with an excess risk of lung cancer even when accounting for smoking and asbestos as possible confounders. These results are also consistent when compared with an internal reference group of shipyard production workers.

We thank the staff of the shipyard Haugesund Mekaniske Verksted for their cooperation throughout the study, $\mathrm{Mr}$ T Kjaersgaard and Mr B Karlsen for their computer assistance, and $\mathrm{Mr} \mathrm{A}$ Engeland from the Cancer Registry for statistical analysis with EGRET.

This project was financed by the Bundesministerium für Forschung und Technologie and the Royal Norwegian Council for Scientific and Industrial Research.

Requests for reprints to: Tor Erik Danielsen, Telemark Central Hospital, Department of Occupational Medicine, N-3906 Porsgrunn, Norway.

1 Simonato L, Fletcher A C, Andersen A, et al. A historical prospective study of European stainless steel, mild steel, and shipyard welders. $\mathrm{Br} \mathcal{F}$ Ind Med 1991;48:145-54.
2 Melkild A, Langård S, Andersen A, Stray Tonnessen JN. Incidence of cancer among welders and other workers in a Norwegian Shipyard. Scand $f$ Work Environ Health 1989;15:387-94.

3 Becker N, Claude J, Frentzel-Beyme R. Cancer risk of arc welders exposed to fumes containing chromium and nickel. Scand $\mathcal{F}$ Work Environ Health 1985;11:75-82.

4 Becker N, Chang-Claude J, Frentzel-Beyme R. Risk of cancer for arc welders in the Federal Republic of Germany: results of a second follow up (1983-8). Br F Ind Med 1991;48: 675-83.

5 Beaumont J, Weiss NS. Lung cancer among welders. $f$ Occup Med 1981;23:839-44.

6 Breslow L, Hoaglin L, Rasmussen G, Abrams HK. Occupations and cigarette smoking as factors in lung cancer. Am $\mathcal{f}$ Public Health 1954;44:171-81.

7 Polednak AP. Mortality among welders, including a group exposed to nickel oxides. Arch Environ Health 1981;36:235-42.

8 Sjögren B, Gustavsson A, Hedstrøm L. Mortality in two cohorts of welders exposed to high- and low-levels of hexavalent chromium. Scand $f$ Work Environ Health 1987; 13:247-51.

9 Tola S, Kalliomäki P-L, Pukkala E, Asp S, Korkala M-L. Incidence of cancer among welders, platers, machinists, and pipe fitters in shipyards and machine shops. $\mathrm{Br} \mathcal{F}$ Ind $\mathrm{Med}$ 1988;45:209-18.

10 Steenland $\mathrm{K}$, Beaumont J, Elliot L. Lung Cancer in mild steel welders. Am f Epidemiol 1991;133:220-9.

11 Hull CJ, Doyle E, Peters JM, Garabrant DH, Bernstein L, Preston-Martin S. Case-control study of lung cancer in Los Angeles county welders. $A m \mathcal{f}$ Ind Med 1989;16:103-12.

12 Langård S. Confounding and effect-modifying factors in epidemiological studies in welders. In: Stern RM, Berlin A, Fletcher AC, Järvisalo J, ed. Proceedings of the international conference on health hazards and biological effects of welding fumes and gases, Copenhagen, 1985: Amsterdam: Excerpta Medica, 1986:439-43.

13 Peto J. Cancer morbidity and mortality studies of welders. In: Stern RM, Berlin A, Fletcher AC, Järvisalo J, ed. Proceedings of the international conference on health hazards and biological effects of welding fumes and gases, Copenhagen, 1985. Amsterdam: Excerpta Medica, 1986:423-34.

14 International Agency for Research of Cancer. Chromium, nickel and welding. Monographs on the evaluation of carcinogenic risks to humans vol 49. Lyon: IARC, 1990:463-474.

15 Lund KE. Tobakksforbruk og røykevaner i Norge [Consumption of tobacco and smoking habits in Norway]. Tidsskr om edruskapsspersmal 1987;3:15-17.

16 Beaumont J, Weiss NS. Mortality of welders, shipfitters and other metal trades workers in Boilermakers Local no 104, AFL-CIO. Am f Epidemiol 1980;112:775-86.

17 Stern RM. Assessment of risk of lung cancer for welders. Arch Environ Health 1983;38:148-55.

18 Dalager NA, Mason TJ, Fraumeni JF, Hoover R, Payne WW. Cancer mortality among workers exposed to zinc chromate paints. F Occup Med 1980;22:25-9.

19 Blot WJ, Harrington $M$, Toledo A, Hoover R, Heath CW, Fraumeni JF. Lung Cancer after employment in shipyards during world ware II. $N$ Engl f Med 1978;299:620-4.

20 McMillan GHG. The health of welders in naval dockyards. f Occup Med 1983;25:727-30.

21 Zeiner-Henriksen $T$. Røykevaner i den norske befolkning [Smoking habits in the Norwegian population]. Tidsskr Nor Laegeforen 1976;96:617-20.

22 Axelson $O$. Aspects on confounding in occupational health epidemiology [Letter to the editor]. Scand $\mathfrak{f}$ Work Environ Health 1978;4:98-102.

23 Steenland K, Beaumont J, Halperin W. Methods of control for smoking in occupational cohort mortality studies. Scand $\mathcal{f}$ Work Environ Health 1984;10:143-9.

24 Siemiatycki J, Wacholder S, Dewar R, Cardis E, Greenwood C, Richardson L. Degree of confounding bias related to smoking, ethnic group, and socioeconomic status in estimates of the associations between occupation and cancer. f Occup Med 1988;30:617-25.

Accepted 18 January 1993 